European Journal of Logistics, Purchasing and Supply Chain Management

Vol.8 No.2, pp.7-23, May 2020

Published by ECRTD UK

ISSN 2054-0930 (Print), ISSN 2054-0949 (Online)

\title{
EXAMINING THE EFFECT OF FLEET MANAGEMENT ON COMPETITIVE ADVANTAGE IN THE TRANSPORT INDUSTRY
}

\author{
Jerry Edem Aflabo \\ Drivers and Vehicle Licensing Authority (DVLA), Denu - Ghana \\ Jerry Jay Kraa \\ Christian Service University College (CSUC) - School of Business, Kumasi - Ghana \\ Leonard Agbenyo \\ Logistics and Supply Chain Management Department, Ho Technical University (HTU) - \\ Ho, Ghana
}

\begin{abstract}
The study assessed the impact of fleet management practices on competitive advantage in the Ghanaian transport sector within the Kumasi metropolis. The study was conducted on a sample of 200 firms with which 178 responses were successfully received representing $89 \%$ response rate. Data was collected using questionnaire. Purposive sampling technique was adopted in selecting respondents. The research designs adopted was explanatory and was analyzed using IBM Statistical Packages for Social Sciences version 20. Regression, correlation and Cronbach alpha coefficients were used for data analysis. The study revealed that, repair and maintenance, fuel and driver management, and training have positive effect on competitive advantage whiles vehicle tracking have an inverse relationship with competitive advantage. The study recommended that, firms should employ experts in the field of fleet management to give them advice on how to implement fleet management practices to enhance service delivery hence giving them an edge over competitors.
\end{abstract}

KEYWORDS: Fleet management, competitive advantage, fuel management, repair and maintenance

\section{INTRODUCTION}

Effective transport management is an important activity in every successful organization in the logistics industry and for that matter fleet management. Businesses that have the intention of excelling in their fleet management operations in today's competitive market have to adopt effective and robust managerial strategies to coordinate resources that will facilitate their success and enable them to gain competitive advantage. The quest to achieve competitive advantage has therefore put pressure on management to deliver faster and 
European Journal of Logistics, Purchasing and Supply Chain Management

Vol.8 No.2, pp.7-23, May 2020

Published by ECRTD UK

ISSN 2054-0930 (Print), ISSN 2054-0949 (Online)

cheaper vehicle utilization fleet management resulting in lower operating cost through better planning (Gitahi and Ogollah, 2014: Jonsson, 2008; Waters, 2009). It is important to note that fleet management for most organizations is seen as having short term effect and short response periods (Martinez et al., 2010). There are varied services offered through transport and most of these services have been segmented into areas of expertise and specialty which aimed at offering valued services through effective fleet management practices (Bask et al., 2010).

Transportation has evolved with mankind and its importance to human life has necessitated the need to improve the means of travelling. The advancement in technology has become the basis for which transportation has come to be a great industry in recent times. Through transport individuals are able to travel long distance by means of cars, ships, aircrafts and many more. It is important to note that logistics as well as transportation services in third world countries have been experiencing changes in various service prospects (Bask et al., 2010). According to Besiou et al., (2012) fleet management should not solely aim at fulfilling companies' objective but should largely consider the environmental impact as well. Fleet management has also become very important that the ability of management to effectively and efficiently coordinate its activities will influence service delivery.

Fleet management has become necessary for transport service delivery systems whether in the public or private sector. There is always a competition between the private and public sector in terms of the kind of transport services they offer and how customers express their satisfaction with services from both sectors. Gitahi and Ogollah (2014) however assert that, the higher expectation of customers and their intolerance for unsatisfactory services have resulted into a competitive atmosphere for fleet operation to provide reliable and costefficient services. There is therefore a need to effectively meet customers' expectations in terms of how fleets are managed so as to enhance service delivery. Ratcliffe (2007) has identified routing and scheduling, fuel management, acquisition of vehicles, vehicle maintenance as well as driver briefing as fundamental to fleet management practices adapted by organizations to deliver effective services to clients. As noted by Gitahi and Ogollah (2014), transportation is an integral part of logistics systems and seen as physical conveyance of resources (people or materials) that existed between places that results in broader concept referred to as supply chain. Aside the numerous benefits of transportation to most organizations in Ghana, it still faces varied obstacles that hinders efficient service delivery and the achievement of overall competitive advantage. Inefficient fleet management results in bad word of mouth, customer compliant and bad image of the organization hence the study assessed the relationship between fleet management and competitive advantage in Ghana. 
European Journal of Logistics, Purchasing and Supply Chain Management

Vol.8 No.2, pp.7-23, May 2020

Published by ECRTD UK

ISSN 2054-0930 (Print), ISSN 2054-0949 (Online)

Whiles the impact of fleet management on the competitive position and overall performance is implied in previous studies, the absent of prior studies that have empirically examine the impact of fleet management on the competitive advantage of firms within the transport industry in developing economies is a major problem. Although previous studies have been conducted to examine transport and fleet management across many countries, majority of these studies mostly explore the impact of fleet management on disaster and relief response, and overall humanitarian logistics perspective (Gitahi and Ogollah, 2014; Pedraza-Martinez and Van Wassenhove, 2012; Besiou et al., 2012, 2011; Martinez et al., 2010; Beamon and Balcik, 2008). This is a major gap in literature and our study addresses this by examining the effect of fleet management on competitive advantage in the commercial transport sector. To realize this, we develop research model which examine the impact of fleet management practices on competitive advantage.

The current study is organized as follows. The introduction section highlights the general background to the study and identifies the research problems, the objective of the study. It further reviews relevant literatures which were followed by the presentation of the research model and hypothesis. The next section discusses the research methods, the result and discussion of findings. The paper then concludes with recommendation and policy implication for future study.

\section{LITERATURE REVIEW}

\section{Fleet Management}

Fleet management can be seen as monitoring and increasing how efficient one can perceive transportation fleet (Gitahi \& Ogollah, 2014). It includes the management of vehicles like cars, ships, vans and trucks. A lot of functions are considered when it comes to fleet management including financing vehicles, maintenance of vehicles, vehicle telematics, driver shifting and roistering, tracking of assets, management of speed, fuel management as well as health and safety management. The primary aim of fleet management is to significantly decrease the risks associated with vehicle operation, efficiency, productivity and minimizing the transportation and staff cost entirely. Accordingly, Besiou et al., (2012) claim that a strategy that ensures sustainable fleet management is one that seeks to minimize environmental effect through the integration of cleaner vehicles and fuels, fuelefficient operation and driving; and by minimizing quantum of traffic it creates on the road.

However, logistics efficiencies are basic to profitable fleet management. The transport sector required to improve its logistics capacity in the field of operation so as to make sure that the organization is performing close to its possible optimal edge. In so doing, organizations need to recruit and select qualified fleet managers/logisticians who have the 
European Journal of Logistics, Purchasing and Supply Chain Management

Vol.8 No.2, pp.7-23, May 2020

Published by ECRTD UK

ISSN 2054-0930 (Print), ISSN 2054-0949 (Online)

technical know-how to operate fleet data management system. It also implies that nonexpendable properties need to be comprehended and acknowledge for their usage and not just in terms of the budget (Kothari, 2008).

Several theories have been developed and utilized to explain issues with regards to fleet management. The following reviewed some of these key theories underpinning transport and fleet management. The concept of replacement theory has to do with the acquisition of new fleet and maintenance of the fleet (Gitahi and Ogollah, 2014). Fleet acquisition and maintenance required a cost of acquiring a new machine compared to the cost of maintenance (Bagui et al., 2012). Many researchers have studied challenges of machine replacement as a critical subject in operation research and management practices over the periods. This theory explained that, a machine is supposed to be replaced when a particular quantity (component) of products part produced with the machine become unserviceable. Once such unserviceable part is identified, then there is need for replacement in order to make the product serviceable.

The second theory applicable to transport and fleet management is the resource-based theory. The theory has an intra-organizational dimension and suggests that performance is a result of firm-specific resources and capabilities (Wernerfelt, 2008). The basis of the resource-based view is that successful firms will identify their long term competitiveness by creating distinctive and unique capabilities, which may often be intangible in nature. This model presents an interrelated organizational concern and proposed that there is positive relationship between performance and resource capabilities within the organization (Wernerfelt, 2008). The resource based view implies that, businesses that are successful tend to project their competitive nature in future based on their distinctive capabilities that tend to be intangible in nature. This is why Rumelt (2008) believed that, a firm's strategy should be designed based on its capabilities as well as its unique resources.

Lastly, studies with respect to technology diffusion theory generally points to the fact that the final beneficiary or the use of a particular innovation is the same person considered as the decision maker or the said adopter (Gitahi and Ogollah, 2014). This person is the one who is exposed to novel products, technology or new services available as well as seek varieties of information with respect to innovations. It is generally becoming clear that the originator or key decision maker of such innovation in any organization does not necessarily become the ultimate beneficiary of the outcome of such decision. The implication of this theory is that although vehicle owners are responsible for making the ultimate decision with regard to what fleet type to use in order to support overall operational activities, they are not directly involved with the day to day running of the vehicles. Key parties at the operational level such as fleet supervisors, drivers and mechanics among 
Vol.8 No.2, pp.7-23, May 2020

Published by ECRTD UK

ISSN 2054-0930 (Print), ISSN 2054-0949 (Online)

others are directly involve in ensuring successful operational objectives are achieved. For instance, vehicle tracking devices are manufactured by independents manufacturers (innovator) which are used by third parties for monitoring and tracking their fleet of vehicles.

\section{RESEARCH MODEL AND HYPOTHESIS}

The research model and hypothesis for the study were developed based on the relationships between the various indicators in the proposed model. The figure below defined the proposed model for the study. Based on this model, the researcher proposes that each of the vehicle management practices highly affect the competitiveness of service delivery. Instrument for measuring vehicle management practices were adapted from previous studies and include repair and maintenance, fuel management, vehicle tracking and driver management (Gitahi and Ogollah, 2014: Ratcliffe, 2007). The hypothesized relationships between these indicators are tested for statistical support.

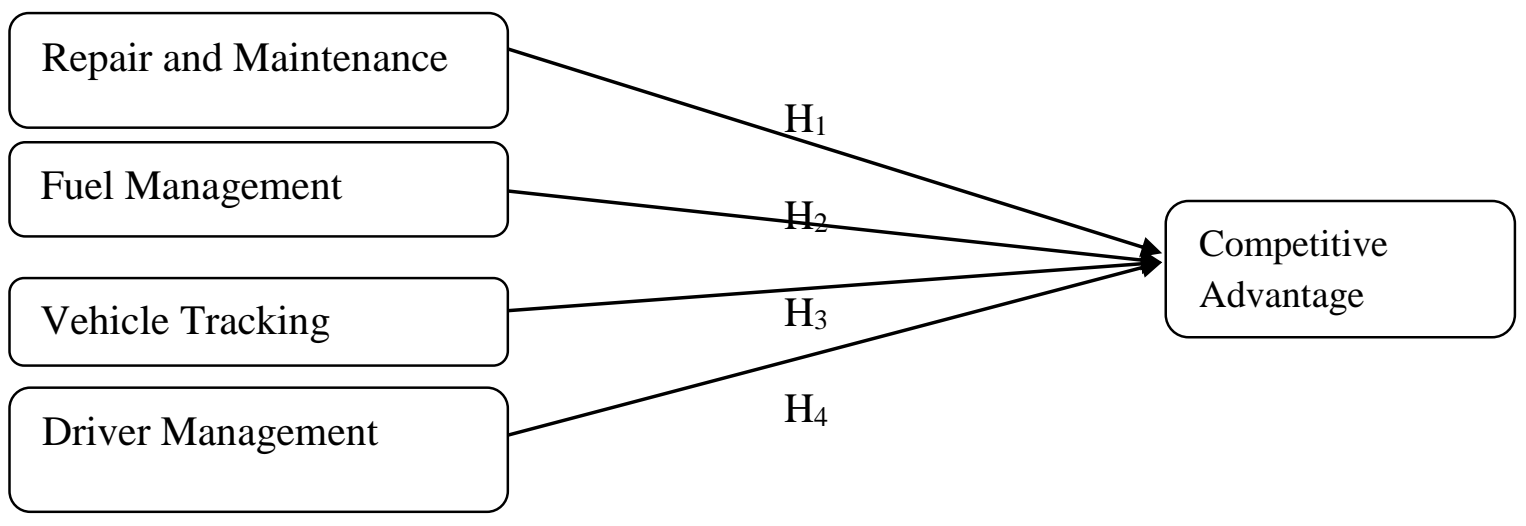

\section{Figure 1.1 Proposed Research Model}

\section{Repair and Maintenance}

Vehicle repair and maintenance is very important to any fleet management organization. Repair and maintenance captured issues of changing oil, routine servicing as well as managing spare parts. Previous studies have revealed that driver training, vehicle maintenance and vehicle design are range of relative low cost measures that can save $10 \%$ or more fuel for fleet operation (Baas et al., 2005; Baas \& Latto 2005). However, Bell (2013) noted that properly changing of oil can help increase the lifespan of the vehicle engine by using fuel additives to ensure that the engine injectors are always clean. When vehicle oil is not change adequately it will permit dirt, particles and acidic substances to degrade the engine parts. Chevrolet (2015) states that oil change is related primarily to gas mileage and can result to a decrease in fuel economy. Having the oil and filter changed is 
European Journal of Logistics, Purchasing and Supply Chain Management

Vol.8 No.2, pp.7-23, May 2020

Published by ECRTD UK

ISSN 2054-0930 (Print), ISSN 2054-0949 (Online)

one of the most common maintenance requirements for the performance of your vehicle. A regularly scheduled oil change is quite possibly one of the most importance maintenance jobs because it is invaluable for the operations of an engine. The study therefore proposed that regular repair and maintenance of vehicle has higher impact competitiveness hence, it is hypothesized that,

$\boldsymbol{H}_{1}:$ Repair and Maintenance positively and significantly impact on competitive advantage

\section{Fuel Management}

Fuel management is an important aspect of fleet operation. Fuel is likened to be the very blood that is in the human body. It facilitates the movement of the vehicle at any point in time. It is crucial to note that while fleet operation and road safety are paramount to service delivery, fuel is a resource that needs to be well managed. Despite the fact that fuel management varies across the organization it nonetheless presents a major cost problem in most setting (Gitahi and Ogollah, 2014). However, implementing formal fuel management programme is effective strategy of making lasting reductions in the cost of fuel for fleet operation. In monitoring vehicle fuel, organizations put fuel control and management designs in place to monitor, save and optimize fuel related cost. Mostly, information about fuel level and consumption is obtained by connecting GPS tracker to an on-board computer or installing fuel level sensor directly in the fuel tank. This activity generates detailed reports which identify drivers who waste the company's fuel and to identify vehicles that use too much fuel. As such, it is important that operators institute the right measures that promote efficient management of fuel since it has major impact on the competitive advantage of the firm. On the basis of this, the study hypothesis that;

\section{$\boldsymbol{H}_{2}:$ Fuel management positively and significantly impact on competitive advantage}

\section{Vehicle Tracking}

Vehicle tracking refers to monitoring the movement of vehicle, either by scanning barcode attached to the vehicle or by using smart tags. Vehicle can also be monitored by using devices that integrate the GPS Global Positioning System and Cellular network or Satellite technology. The vehicle tracking directed to general fleet management system, ensure the tracking all goods and physical items that have been provided to a driver or loaded on a vehicle. It is believed that, information systems that are used for coordination and routing services in the field positively impact on routine increment and performance of fleet (Martinez et al., 2011). However, there is basically inadequate data-base as well as funds to buy such a system. As noted by Huang, Smilowitz, and Balcik (2012), logisticians make routing and delivery scheduling decisions based on the insights and experiences they have about particular information. With advancement in communication technology in the 
European Journal of Logistics, Purchasing and Supply Chain Management

Vol.8 No.2, pp.7-23, May 2020

Published by ECRTD UK

ISSN 2054-0930 (Print), ISSN 2054-0949 (Online)

business world, most organizations are engaging in innovative forms of planning through the utilization of electronic data interchange (EDI) as well as radio frequency identification (RFID) and satellite navigation (Waters, 2009) to collect the right information about vehicle movement which result in higher operational efficiency. On the basis of this development, we hypothesis that;

$\boldsymbol{H}_{3}$ : Vehicle tracking positively and significantly impact on competitive advantage

\section{Driver Management and Training}

Keeping vehicles in good shapes and condition is a great responsibility of drivers. Drivers must be provided with the requisite training to take care of vehicles and should be able to attend to problems that arise when using the vehicle. Vehicle inspection is also very important for fleet management to be effective. Fleet vehicles must be properly inspected on regularly basis to check whether they are in good conditions to work on the road or whether vehicle meet regulations in the country of operation. The driver should be able to provide first aid for the vehicle when a break down occurs on the road whiles ensuring that they are able to quickly identify and respond to problems immediately.

Resilience training has especially been proven to be an effective means to proactively improve workplace wellbeing and may be considered foremost in any intervention strategy to address workplace stress (Hesketh et al., 2015). The training of employees on a largescale programme with regards to the usability of new technology is not possible in many organizations. However, organizations achieve this by providing information to user department in the most appropriate way. Training manuals are also given to employees to encourage easy and quick adaptation of new machines in the organization. Other methods such as short presentation as well as posters and notices with tips on how improvements can be made are important in enhancing driver's skills and knowledge in delivering quality service delivery. Therefore, we propose that driver management and training has a greater impact on service delivery and overall competitive advantage. Hence, the following hypothesis:

\section{$\boldsymbol{H}_{4}$ : Drivers management positively and significantly impact on competitive advantage}

\section{Competitive Advantage}

Some firms gain advantage over others because they can conduct certain organizational processes in a better manner relative to their competitors. Competitive advantage is achieved from controlling important resources that allow firms to undertake activities better or more cost effectively than their competitors (Collis and Montgomery 1995). Porter (1980) identified three generic strategies that enable organization to achieve competitive 
European Journal of Logistics, Purchasing and Supply Chain Management

Vol.8 No.2, pp.7-23, May 2020

Published by ECRTD UK

ISSN 2054-0930 (Print), ISSN 2054-0949 (Online)

advantage namely cost leadership, differentiation and focus strategy. Due to the intense competition in the business market, almost all firms seek to achieve competitive advantage over competitors. Accordingly, Barney (2007) suggests that a competitive advantage is achieved when a firm is implementing a value creating strategy not simultaneously being implemented by any current or potential player. Such strategy must focus on how businesses can take advantage of a specific market position, operates efficiently, attracts customers and successfully outsmarts competitors and become a leader both in the shortterm and in the long term (Barone \& Decarlo, 2003; Johnson \& Scholes, 2002). Barone and Decarlo (2003) argue that the tasks of crafting and executing strategies are at the heart of managing business enterprises and winning in the market place. Gaining competitive advantage is therefore seen as a major boost for the business because of the numerous advantages it will give to the firm.

In addition, firm gained competitive advantage if it can generate more economic value than the marginal (breakeven) competitor (Peteraf \& Barney, 2003). Organizations measure their competitive advantage from different perspectives such delivery time, quality, economic value, customer-base quantity produced and others. Delivery time is viewed as the time taken to carry out task from the beginning to the end. Firms often consider the time frame to deliver service to customers as competing factor. According to Stonebrake and Leong (1994), delivery time becomes a source of competitive advantage if only firms can reduce the time taken to receiving, accepting and providing customer order or product or services. Quality can be defined in terms of adding a unique feature to product to enhance their competitive attractiveness so as to benefit customers in the final stage (Rousan \& Qawasmeh, 2009).

\section{RESEARCH METHODOLOGY}

Explanatory research design was adopted. Explanatory research determines the causal relationships among variables (Saunders et al., 2009). The survey method was also used to gather information that was employed in quantitative analysis generating data used in the analysis. With the help of the survey strategy, it gave the researcher more control over the search process (Saunders et al. 2009). Population is the composition of people or cases which a particular characteristic that researcher want to explore. According to Kumekpor (2002), research population is a collection of various cases when triggers an investigation of the same kinds. The population of this study comprised managements that have control over fleet in Ghana precisely in Kumasi metropolis. This management is made up of transport officers and any other officers in charge of managing fleet. 
Studying a whole or entire population may not be possible some time due to lack of resources or limited time and the use of sample from such population will just be good enough to conduct a particular study. In selecting the sample from the population for the study, 200 representatives were chosen. The sample chosen can be considered as enough representation as in literature that proposed a sample of 30 for a statistical data when the characteristics of the respondents are homogeneous. As such, 200 participants are enough for the study (Stutely, 2003). In selecting the sample, purposive sampling techniques was adopted. Purposively, the researchers identify and contacted key transport managers and officers in charge of managing fleet of cars with high level of information on their operations.

Data collection tool was questionnaires administered to the participants. The questionnaires were design in a close ended manner for respondents to tick their responses on a 5-point likert scale with $1=$ strongly disagree to $5=$ strongly agree. The questionnaires were personally delivered to managers at their places of work. After a successful gathering of data from respondents, the data was coded and given interpretation. The software that aided the analysis is the Statistical Package for Social Sciences (SPSS). After a thorough screening of the data to make sure the omissions and commissions are rectified, the analysis was then run. Multiple linear regression and correlations were the statistical techniques adopted in the interpretation of the data. The reliability of the data used was also tested using Cronbach alpha coefficient to ascertain the internal consistencies among the variables used for the study.

\section{RESULT OF THE STUDY}

\section{Reliability of Variables Using Cronbach Alpha}

One of the important activities of a research project is to run a reliability test for the variables used in the study. The reliability of variables basically is defined to mean the internal consistency of the variables used to measure the predictor variable and dependent variables. Thus, the extent to which the variables used hung together to measure the same construct. Over the years, researchers have utilized varying degree of measuring tools to conduct the reliability test in various studies. These tools include; Split-half, Guttman, Parallel, Cronbach alpha among others. In this study, the research used Cronbach alpha which is a widely used tool for checking the internal consistency of the variables in a research in order to grant the study the degree of reliability.

In order get the best result by using Cronbach alpha the principle needs to be observed. According to Devellis (2003), Cronbach alpha coefficient should be above 0.7. Cronbach alpha values above 0.7 are acceptable and values that are above 0.8 are preferable. In this 
study, the reliability test run showed a Cronbach alpha of $0.710,0.704,0.759,0.712$, and 0.821 for Repair and maintenance, fuel management, vehicle tracking, competitive advantage. This shows a good reliability measure of variables. Cronbach alpha reliability statistics was shown in table 4.1 below

\begin{tabular}{lcc}
\hline Variables & Alpha value & Number of items \\
\hline Repair and management & .710 & 3 \\
Fuel management & .704 & 5 \\
Vehicle tracking & .759 & 5 \\
Driver management and training & .712 & 5 \\
Competitive advantage & .821 & 6
\end{tabular}

\section{Table 1 Reliability of Variables using Cronbach alpha}

\section{Correlation Matrix}

Checking for multicolloneality is very important so as to ascertain the variables are highly correlated to warranty dropping some variable or variables in order to ensure robustness. Pearson correlation statistics was therefore conducted among the variables used. Table 2 below shows the correlation results.

\begin{tabular}{|l|l|l|l|l|l|}
\hline & RM & FM & VT & DMT & CA \\
\hline RM & 1 & & & & \\
\hline FM & $.455^{* *}$ & 1 & & & \\
\hline VT & $.455^{* *}$ & $.374^{* *}$ & 1 & & \\
\hline DMT & $.347^{* *}$ & $.344^{* *}$ & $.428^{* *}$ & 1 & \\
\hline CA & $.272^{* *}$ & $.216^{* *}$ & $.079^{* *}$ & $.307^{* *}$ & 1 \\
\hline
\end{tabular}

Table 2 Correlation between Variables

**Correlation is significant at the 0.01 level (2-tailed). Key: RM=Repair and maintenance, $\mathrm{FM}=$ Fuel management, $\mathrm{VT}=$ Vehicle tracking, $\mathrm{CA}=$ Competitive Advantage, $\mathrm{DMT}=$ Driver management and training.

In quantitative research the concept of correlation is one of the techniques invariably used to assess whether there is a relationship between two or more variables. Statisticians have developed and used statistical tools which enable them to make statistical analyses about the relationship between variables. Thus, to check the extent to which a variable account for by another variable. In order to check whether the strength of the relationship between the variables will affect further statistical analysis, a multicollinearity test was performed 
European Journal of Logistics, Purchasing and Supply Chain Management

Vol.8 No.2, pp.7-23, May 2020

Published by ECRTD UK

ISSN 2054-0930 (Print), ISSN 2054-0949 (Online)

using the correlation statistics. For the method to be robust, it is suggested that the correlation statistics should not exceed 0.7 (Hair. et al., 2014; Pallant, 2007). This means that, multicollinearity is not a threat to this analysis. There is also a significant relationship between the variables used. As shown on Table 2, all the variables fall within range as suggested in literature.

\section{DISCUSSION OF FINDINGS}

\section{Effect of Fleet Management Practices on Competitive Advantage}

In assessing the effect of fleet management practices on competitive advantage of firms, multiple regression analysis was conducted. Repair and maintenance, fuel management, vehicle tracking and driver management and training constituting fleet management practices were used as independent variables while competitive advantage was used as the dependent variable. The confidence level is $95 \%$ at $5 \%$ margin of error. Table 3, 4 and 5 shows the model summary, ANOVA and coefficient statistics from the regression result.

\begin{tabular}{|l|l|l|l|l|}
\hline Model & R & R Square & Adjusted R Square & Std. Error of the Estimate \\
\hline 1 & $.385^{\mathrm{a}}$ & .148 & .128 & .37350 \\
\hline
\end{tabular}

Table 3 Model Summary

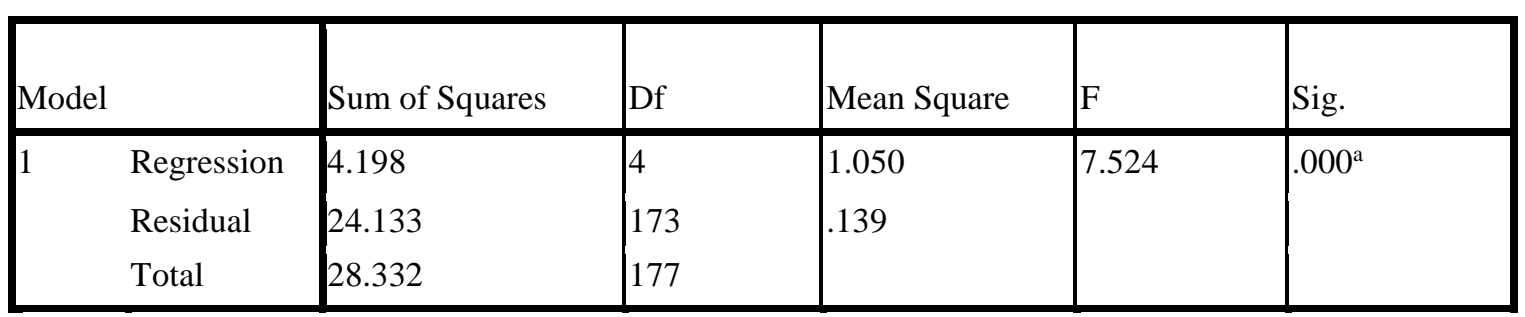

Table 4 ANOVA ${ }^{b}$

a. Predictors: (Constant), Driver management and training, Fuel management, Vehicle tracking, Repair and maintenance

\begin{tabular}{|c|c|c|c|c|c|c|}
\hline \multirow{2}{*}{\multicolumn{2}{|c|}{ Model }} & \multicolumn{2}{|c|}{ Unstandardized Coefficients } & \multirow{2}{*}{\begin{tabular}{|r}
$\begin{array}{l}\text { Standardized } \\
\text { Coefficients }\end{array}$ \\
Beta
\end{tabular}} & \multirow[b]{2}{*}{$\mathrm{t}$} & \multirow[b]{2}{*}{ Sig. } \\
\hline & & B & Std. Error & & & \\
\hline \multirow[t]{5}{*}{1} & (Constant) & 2.612 & .300 & & 8.713 & .000 \\
\hline & Repair and maintenance & .174 & .069 & .213 & 2.519 & .013 \\
\hline & Fuel management & .075 & .070 & .088 & 1.077 & .283 \\
\hline & Vehicle tracking & -.134 & .067 & -.169 & -2.005 & .046 \\
\hline & $\begin{array}{l}\text { Driver management and } \\
\text { training }\end{array}$ & .216 & .063 & .275 & 3.432 & .001 \\
\hline
\end{tabular}




\begin{tabular}{|l|l|l|l|l|}
\hline Model & R & R Square & Adjusted R Square & Std. Error of the Estimate \\
\hline 1 & $.385^{\mathrm{a}}$ & .148 & .128 & .37350 \\
\hline
\end{tabular}

Table 5 Coefficients ${ }^{\mathrm{a}}$

a. Dependent Variable: Competitive advantage

\section{Regression Equation}

The output in the regression table represents the multiple regressions to establish the effect of fleet management practices on competitive advantage. The regressions equation was therefore $\mathrm{Y}=\mathrm{a}+\mathrm{b}_{1} \mathrm{X}_{1}+\mathrm{b}_{2} \mathrm{X}_{2}+\mathrm{b}_{3} \mathrm{X}_{3}+\mathrm{b}_{4} \mathrm{X}_{4}$. When the values from the output are computed, the equation becomes; $\mathrm{Y}=2.612+.174\left(\mathrm{X}_{1}\right)+.075\left(\mathrm{X}_{2}\right)+-.134\left(\mathrm{X}_{3}\right)+.216\left(\mathrm{X}_{4}\right)$. From the regression output, the result shows that there is a moderate relationship between fleet management and competitive advantage of firms with a value of .385 . The $\mathrm{R}$ square value indicates that $14.8 \%(.148)$ of the competitive advantage among firms could be accounted for by fleet management practices. From the ANOVA result, it shows that, the combined effect of repair and maintenance, fuel management, vehicle tracking and driver management and training (independents variables) on competitive advantage is statistically significant $\left(\mathrm{F}=7.524 ; \mathrm{p}=.000^{\mathrm{a}}\right)$. An F-statistics of 4 shows that the model is fit and therefore a value of 7.524 indicate that the model is fit.

\section{Coefficient, Significance of the Model and Beta}

The regression result shows that, the coefficient value for repair and maintenance is .174 showing a positive impact on competitive advantage. All things being equal, thus when the other independent variables (fuel management, vehicle tracking, and driver management and training) are held constant, competitive advantage of firms will increase. The results also show that, repair and maintenance is statistically significant and is making great contribution to the prediction of competitive advantage with t value of 2.519 and significant of .013. The implication is that, if firms engage repair and maintenance of vehicle as a fleet management practice they will increase the competitive advantage in the firm and increase output at a lower cost, meeting clients demand on time and delivery of quality service over competitors.

With respect to fuel management the regression results show that, there is a positive relationship between fuel management and competitive advantage with coefficient value of .075. This implies that when the other independent variables (repair and maintenance, vehicle tracking and driver management and training) are held constant, competitive advantage of firms will increase. Fuel management is statistically not significant meaning it does not make any unique contribution to the prediction of competitive advantage with $t$ value of 1.077 and significant at 0.28 . The implication is that, even though there is a positive impact of fuel management as a fleet management practice on competitive 
advantage, it does not really add to meeting clients demand on time, increasing output at lower cost and delivering of quality service.

Vehicle tracking was assessed and the regression results shows that it has negative impact on competitive advantage with a coefficient value of -.134. This implies that, when the other variables (repair and maintenance, fuel management and driver management and training) are held constant, competitive advantage will decrease. However, vehicle tracking is statistically significant and making a unique contribution to the prediction of competitive advantage among firms with $t$ value of -2.005 and significant at .046 . It can further be explained that, vehicle tracking has taken a great toll on firms that initiate it as a fleet management practice in the form of the cost involved in fleet administration, maintenance scheduling and dispatching of vehicle.

Driver management and training is an integral part of fleet management. The regression result shows that driver management and training has a positive impact on the competitive advantage of firms with coefficient value of .216 . This shows that if the other variables are held constant (repair and maintenance, fuel management, vehicle tracking) competitive advantage will increase at an increase practices of driver management and training and vice versa. Driver management and training is statistically significant and making a unique contribution to the prediction of competitive advantage with $t$ value of .216 and significant at .001. The implication is that more firms give attention to supervising and planning of driver activities, engage in appropriate hiring processes of drivers and give maintenance training to drivers.

In comparing the contribution of each independent variable to the prediction of the dependent variable, the beta values (ignoring the negative sign) are used to see which variable make the strongest contribution to explaining competitive advantage of firms. Repair and maintenance, fuel management, vehicle tracking and driver management and training have beta values of .213, .088, -.169 and .275 respectively. Looking at the values, the biggest beta value is .275 , which is driver management and training. This implies that, driver management and training makes the greatest contribution to explaining the competitive advantage of firms when the variances in the model are controlled. 
European Journal of Logistics, Purchasing and Supply Chain Management

Vol.8 No.2, pp.7-23, May 2020

Published by ECRTD UK

ISSN 2054-0930 (Print), ISSN 2054-0949 (Online)

\section{Summary of Hypothesized Construct}

\begin{tabular}{|l|l|c|c|l|l|}
\hline $\mathbf{H}$ & Hypothesis Relationship & $\begin{array}{l}\text { Path } \\
\text { Coefficient }\end{array}$ & $\begin{array}{l}\text { T - } \\
\text { Statistics }\end{array}$ & $\begin{array}{l}\text { Significant } \\
\text { / Not }\end{array}$ & $\begin{array}{l}\text { Hypothesis } \\
\text { Supported }\end{array}$ \\
\hline$H_{1}$ & $\begin{array}{l}\text { Repair and maintenance } \\
\text { Competitive advantage }\end{array}$ & 0.174 & 2.519 & $\begin{array}{l}\text { Significant } \\
\text { at } 0.013\end{array}$ & $\begin{array}{l}\text { Supported } \\
\text { at } p<0.01\end{array}$ \\
\hline$H_{2}$ & $\begin{array}{l}\text { Fuel management } \\
\text { Competitive advantage }\end{array}$ & 0.075 & 1.077 & $\begin{array}{l}\text { Significant } \\
\text { at } 0.283\end{array}$ & $\begin{array}{l}\text { Supported } \\
\text { at } p<0.01\end{array}$ \\
\hline$H_{3}$ & $\begin{array}{l}\text { Vehicle tracking } \\
\text { Competitive advantage } \rightarrow\end{array}$ & -0.134 & -2.005 & $\begin{array}{l}\text { Significant } \\
\text { at } 0.046\end{array}$ & $\begin{array}{l}\text { Not } \\
\text { Supported } \\
\text { at } p<0.01\end{array}$ \\
\hline$H_{4}$ & $\begin{array}{l}\text { Drivers management and } \\
\text { training } \rightarrow \text { Competitive } \\
\text { advantage }\end{array}$ & 0.216 & 3.432 & $\begin{array}{l}\text { Significant } \\
\text { at } 0.001\end{array}$ & $\begin{array}{l}\text { Supported } \\
\text { at } p<0.01\end{array}$ \\
\hline
\end{tabular}

Table 6 Summary of Hypothesized Result

\section{CONCLUSION}

This study was conducted on the premise of assessing the effect of fleet management on service delivery of firms. The study reveals that fleet management plays an important role in service delivery and also contributes significantly to the competitive advantage in many regards. With effective and efficient fleet management practices, firms are now able to overcome some of the problems they face during service delivery in terms of meeting customers demand and providing timely service to client as promised, hence given firms an edge over competitors in their business operation. It is also worthwhile noting that, despite the many improvements firms have gain through adoption of fleet management practices, there still remain major challenges that plague effective fleet management practices. In summary, the study confirmed that fleet management practices are important factors to enhancing competitiveness of the firm.

\section{Policy Implication and Future Research Direction}

The study offers both theoretical and practical implication contributions. For theory, this study has developed and tested a model which examine the effect of fleet management on competitive advantage. The result provides a clear indication that fleet management practices have a major impact on the competitiveness of firms. In practice, the study offered guideline to management and policy makers on specific fleet management practices or combination of practices that provide a source of competitive advantage. However, the study was limited to only one industry although we admit the result may have some variation for other industries. Future studies should consider exploring fleet management 
European Journal of Logistics, Purchasing and Supply Chain Management

Vol.8 No.2, pp.7-23, May 2020

Published by ECRTD UK

ISSN 2054-0930 (Print), ISSN 2054-0949 (Online)

impact on competitive advantage in others industries like manufacturing and bulk oil storage and transportation.

\section{References}

Aaker, D. A. (1995), Strategic marketing management (2nd ed.). New York: John Wiley $\&$ Sons

Baas, P \& D Latto (2005) Heavy vehicle efficiency. Transport Engineering Research New Zealand 56 (6), pp. 66-91

Balcik, B., Beamon, B.M., Krejci, C.C., Muramatsu, K.M. \& Ramirez, M. (2010). Coordination in humanitarian relief chains: practices, challenges \& opportunities", International Journal of Production Economics, Vol. 126 No. 1, pp. 22-34.

Barney, J. B. (2002). Gaining \& sustaining competitive advantage. New Jersey: Prentice Hall.

Bask, A.H., Tinnilä, M. \& Rajahonka, M. (2010). Matching service strategies, business models \& modular business processes. Business Process Management Journal, Vol. 16 (1), 153-180.

Beamon, B. M. \& Balcik, B. (2009) Performance measures in humanitarian relief chains. Journal of Public Sector Management, 21 (1) 4-25

Besiou, M., Martinez, A. J.P. \& Van Wassenhove, L. N. (2012). The effect of earmarked funding on fleet management for relief \& development. INSEAD, Working Paper.

Botan, C., Frey, L.R., \& Kreps, G. (2000). Investigating communication: An introduction to research methods: Boston: Allyn \& Bacon.

Collins, A., Henchion, M. \& O'Reilly, P. (2009). Logistics customer service: performance of Irish food exporters. International Journal of Retail \& Distribution Management, Vol. 29 (1), 6-15.

Collins, D. J. \& Montgomery, C. (1995) Competing on resources: strategy in the 1990s. Harvard Business Review, 73, 118-128.

Evans, J. R. \& Barry B. (2007). Marketing, (7th ed.), Upper Saddle River, NJ: Prentice Hall.

Gitahi, M. P. \& Ogollah, K (2014). Influence of Fleet Management Practices on Service Delivery to Refugees in United Nations High Commissioner for Refugees Kenya Programme. European Journal of Business Management, 2 (1), 336-341.

Hesketh, I., Cooper, C. \& Ivy, J. (2015), "Well-being, austerity \& policing: is it worth investing in resilience training?", The Police Journal: Theory, Practice \& Principles, Personal communications, Vol. 88 No. 3, pp. 220-230,

Higgins, M. (2004). Grocery shopping enters a new age: H \& H gizmo lets you scan items before you get to the checkout counter. Wall Street Journal, March 30, p. D4. 
European Journal of Logistics, Purchasing and Supply Chain Management

Vol.8 No.2, pp.7-23, May 2020

Published by ECRTD UK

ISSN 2054-0930 (Print), ISSN 2054-0949 (Online)

Huang, M., Smilowitz, K., \& Balcik, B. (2012). Models for relief routing: Equity, efficiency \& efficacy. Transportation Research Part E 48, 2-18. GRA 19003: Master Thesis 01.09.2012 117

Johnson, G. \& Scholes, K. (2006). Exploring Corporate Strategy (6th Ed.). London, Prentice Hall.

Kothari, T. (2008). Logistics Training: Necessity or Luxury? Forced Migration review, (22), 60 .

Kotler, A. (2006). Define Then Achieve Fleet Optimization. Power Engineering, November, 116-122.

Kotler, P. (2003). Marketing Management: (11th ed.). New Jersey: Prentice- Hall, Inc., Eaglewood Cliff, pp. 22-75.

LaBarbera, P. A., \& D. Mazursky (2003). A longitudinal assessment of consumer satisfaction/dissatisfaction: The dynamic aspect of the cognitive process. Journal of Marketing Research 20 (4): 393-404.

Martinez, A. J. P., Stapleton, O. \& Van Wassenhove, L.N. (2011). Field Vehicle Fleet Management in Humanitarian Operations: A case-based approach. Journal of Operations Management 29, 404-421.

McKenna, F, AE Waylen \& ME Burkes (1998). Male \& female drivers: how different are they? Basingstoke, AA Foundation for Road Safety Research.

Mugenda, M. O. (2008). Predicting the Unpredictable \& Forecasting. International Humanitarian Response. Nairobi.

Neuman, W.L. (2005) Social Research Methods (6 $6^{\text {th }}$ ed.). London: Pearson.

Pedraza-Martinez, A. J. \& Van Wassenhove, L. N. (2012). Transportation \& vehicle fleet management in humanitarian logistics: Challenges for future research. The Association of European Operational Research Societies, 1:185-196

Pedraza-Martinez, A.J. \& Van Wassenhove, L.N. (2012), "Transportation \& vehicle fleet management in humanitarian logistics: challenges for future research", EURO Journal on Transportation \& Logistics, Vol. 1 Nos 1-2, pp. 185-196.

Persaud, B, G Bahar, A Smiley, E Hauer \& J Proietti (1999). Applying the science of highway safety to effect highway improvements - a multi-disciplinary approach. Canadian ITE Meeting, Montreal, Quebec; April 1999. 18 pp.

Porter, M.E. (1996). What is strategy? Harvard Business Review, 6, 61-78.

Pruyn, A., \& Smidts. A. (1998). Effects of waiting on the satisfaction with the service: Beyond objective time measurements. International Journal of Research in Marketing 15 (4): 321-34.

Ratcliffe, (2007) in Gitahi, M. P . \& Ogollah, K (2014). Influence of Fleet Management Practices on Service Delivery to Refugees in United Nations High Commissioner 
European Journal of Logistics, Purchasing and Supply Chain Management

Vol.8 No.2, pp.7-23, May 2020

Published by ECRTD UK

ISSN 2054-0930 (Print), ISSN 2054-0949 (Online)

for Refugees Kenya Programme. European Journal of Business Management, 2 (1), 336-341.

Robson, C. (2002). Real World Research (2 ${ }^{\text {nd }}$ Ed.). Oxford: Blackwell

Rucińska, D. (2010), "Potrzeby transportowe", in Rydzykowski, W. \& Wojewódzka-Król, K. (Eds), Problemy transportu w rozszerzonej UE, Polskie Wydawnictwo Naukowe PWN, Warszawa, pp. 25-38.

Rumelt (2008) in Gitahi, M. P . \& Ogollah, K (2014). Influence of Fleet Management Practices on Service Delivery to Refugees in United Nations High Commissioner for Refugees Kenya Programme. European Journal of Business Management, 2 (1), 336-341.

Saunders, M. Philip, L. \& Adrian, T. (2016). Research Method for Business Students. (6 $^{\text {th }}$ Ed.). Pearson Education New York.

Sheu, C., \& Babbar. S. (1996). A managerial assessment of the waiting-time performance for alternative service process designs. The international journal of management science 24 (6): 689, 703.

Tumi, D. (2005). Customer Service is an Attitude. University Press Accra: pp. 21 - 44.

Waters, D. (2009). Supply Chain Management: an introduction to logistics (2 ${ }^{\text {nd }}$ Ed.). London, Palgrave Macmillian.

Wernerfelt, (2008) in Gitahi, M. P. \& Ogollah, K (2014). Influence of Fleet Management Practices on Service Delivery to Refugees in United Nations High Commissioner for Refugees Kenya Programme. European Journal of Business Management, 2 (1), 336-341.

Zeithml, V.A. \& Bitner, M.J. (2003). Services Marketing: Integrating Customer Focus Across the Firm. Boston. Canadian Journal of Administration Science 13 (3), pp .264-76. 